\title{
OS DESAFIOS E UMA NOVA POSSIBILIDADE PARA O ENSINO DE CIÊNCIAS PARA ALUNOS SURDOS: O ESTUDO DOS SERES VIVOS
}

\author{
Semana Online Científica de Educação, 1a edição, de 25/10/2021 a 27/10/2021
}

ISBN dos Anais: 978-65-81152-18-5

\begin{abstract}
MALDONADO; Raquel Fonseca ${ }^{1}$, BEZERRA; Mariana Leite Marques da Silva ${ }^{2}$, SANTANA; Tábata de Oliveira ${ }^{3}$, TRINDADE; Edison Souza 4
\end{abstract}

\section{RESUMO}

O ensino de Ciências permeia a vida acadêmica dos alunos das instituições de ensino, pois colabora na formação do cidadão para ser protagonista do mundo e dos fenômenos naturais ao seu redor. A uma educação inclusiva para surdos e regulamentada nos currículos de Ensino Básico no Brasil e preconiza o bilinguismo LIBRAS/Português, mas na prática não acontece. Nos deparamos com escassos estudos e materiais didáticos voltados, o que dificulta o processo de ensino-aprendizagem e, além disso, a realidade linguística da maioria dos alunos surdos é: não são alfabetizados no português (L2), não dominam a LIBRAS (L1) e chegam para o ensino de Ciências com a perspectiva de aprenderem uma "terceira linguagem", a linguagem própria da Ciência. Entretanto, apesar da maior barreira para a aprendizagem desses alunos ser linguística, não é impeditiva para a aquisição dos conhecimentos científicos, mas que acoplados ao aspecto visual/espacial, é possível conduzir o aluno a aprendizagem, de forma simultânea, dos signos imagético das Ciências, da LIBRAS e das nomenclaturas em português. Neste trabalho, trazemos um relato de experiência de produção de material didático bilingue e "não estático" para alunos surdos baseado que vai além da necessidade de definições traduzidas Português/Libras da modalidade oral-auditiva. A ferramenta Scratch para a produção do material didático foi escolhida devido fazer uso de uma linguagem de programação de fácil compreensão e apropriada metodologicamente para exploração visual e imagética em movimento, para isso foi feita a inserção de "atores" na ferramenta Scratch no formato gif, possibilitando a comunicação gestovisual. Foi possível a produção de 4 materiais dinâmicos, sequenciais e que se complementam, abordando o assunto dos reinos/grupos de classificação dos seres vivos. O presente trabalho vem mostrar uma nova possibilidade de produção de material didático para atender os estilos e estratégias de cada aluno na construção do conhecimento.

PALAVRAS-CHAVE: Acessibilidade, Gesto-visual, Scratch, Seres Vivos, Signos Imagéticos 